\title{
Effects of Insulin-Like Growth Factor-I on Expression of Suppressor of Cytokine Signaling-3 in $\mathrm{C} 2 \mathrm{C} 12$ Myotube
}

\author{
Hye Jin Kim and Won Jun Lee*
}

Department of Exercise Science, College of Health Sciences, Ewha Womans University, Seoul 120-750, Korea

Received May 31, 2011 /Revised September 22, 2011 /Accepted September 23, 2011

\begin{abstract}
It is well known that both insulin-like growth factor-I and suppressor of cytokine signaling-3 (SOCS-3) are known to modulate various aspects of physiology in skeletal muscle cells. Furthermore, although SOCS-3 expression is related to insulin resistance in non-skeletal muscle cells and is known to interact with insulin-like growth factor-I receptor, the effect of IGF-I on SOCS-3 gene expression in skeletal muscle cells is presently unknown. C2C12 myotubes were treated with different concentrations (0-200 $\mathrm{ng} / \mathrm{ml}$ ) of IGF-I or for various periods of time (3-72 hr). Immunofluorescent staining image revealed that IGF-I induced SOCS-3 protein expression in a dose-dependent manner. Western blot data also showed that SOCS-3 proteins were induced by IGF-I $(200 \mathrm{ng} / \mathrm{ml})$ in C2C12 myotubes in a time-dependent manner. The level of SOCS-3 mRNA was also significantly increased after $3 \mathrm{hr}$ of IGF-I $(10-100 \mathrm{ng} / \mathrm{ml})$ treatment. However, the levels of SOCS-3 mRNA were significantly decreased after 24 and $48 \mathrm{hr}$ of IGF-I $(10-100 \mathrm{ng} / \mathrm{ml})$ treatment compared to the control. In conclusion, SOCS-3 protein is induced by IGF-I treatment in $\mathrm{C} 2 \mathrm{C} 12$ skeletal muscle cells and this induction is regulated pretranslationally. The modulating effect of IGF-I on SOCS-3 expression may be an important regulator of gene expression in skeletal muscle cells.
\end{abstract}

Key words : Insulin-like growth factor-I, suppressor of cytokine signaling-3, C2C12 myotube

\section{서 론}

Suppressor of cytokine signaling (SOCS) family는 사이 토카인(cytokine)이나 성장인자(growth factor)들의 세포내 신호전달을 조절하는데 있어 부적 반응고리(feedback loop) 로 작용하는 유전자로 알려져 있다[1,2]. SOCS family는 8개 (cis and SOCS-1-7)로 구성되어 있으며, 이들은 각각의 $\mathrm{SH} 2$-domain을 가지고, 이 영역을 통해 SOCS 단백질들이 다양한 신호전달 단백질 또는 세포막에 인접한 수용체 (receptor)들의 주요 tyrosine 인산화 영역과 상호작용 하도 록 하는 역할을 한다[1,5]. 이러한 SOCS 유전자들은 여러 조 직에서 사이토카인[9], 성장인자[30], 그리고 호르몬[8,14,30] 등에 의해 발현이 증가한다.

최근 근육조직 및 근육 세포의 형성과정에 있어 suppressor of cytokine signaling-3 (SOCS-3) 유전자가 중요한 매개체로 써의 역할을 한다는 사실이 증명되었다[7,30]. 근육 세포의 분 화 과정에서 SOCS-3 유전자의 mRNA 발현이 증가되었으며, SOCS-3를 과발현 시키자 근육관련 전사인자인 SRF (serum respose factor)의 전사활성화가 급격히 증가하였음을 보고하 였다[30]. 나아가 성장호르몬에 의한 근육에서의 SOCS-3 유전 자의 발현에 관한 연구들도 보고되었는데[14], 사람의 근육 조

\footnotetext{
*Corresponding author

Tel : +82-2-3277-2563, Fax : +82-2-3277-2846

E-mail : jun@ewha.ac.kr
}

직에 성장 호르몬을 주입하자 SOCS-3 mRNA가 유의하게 증 가하였으며[24], 쥐의 간, 근육, 지방 조직에서도 성장호르몬에 의해 SOCS-3의 mRNA 발현이 증가하였다는 연구 결과가 보 고된 바 있다[34].

한편, SOCS-3 유전자 발현 증가는 다양한 조직에서 인슐린 저항성(insulin resistance)을 증가시키고, 반대로 SOCS-3 발현 의 감소는 인슐린 민감성(insulin sensitivity)을 높여주어, SOCS-3가 인슐린 조절 기전에 중요한 역할을 한다고 보고되 었다 $[8,28,29]$. Ueki 등[36]에 따르면 간(liver) 세포에서 SOCS-3 유전자의 과발현이 인슐린 저항성을 유도하였으며, SOCS-3가 지방세포(adipocyte) [29]와 COS-7 세포[9]에서도 인슐린 신호전달을 조절하는 능력을 가지고 있다고 보고하였 다. 이와 같은 연구 결과들을 바탕으로 골격근에서 SOCS-3와 인슐린의 관계에 대한 연구들이 진행되었다. 한 연구에 따르 면 $\mathrm{C} 2 \mathrm{C} 12$ 근육 세포에 인슐린을 처리하자 SOCS-3의 mRNA 가 유의하게 증가하였음을 보고하였다[28]. 골격근은 대표적 인 인슐린 민감성 조직으로 알려져 있을 뿐만 아니라 규칙적 인 신체활동은 인슐린 저항성을 낮춰주고, 인슐린 민감성을 증진시킨다고 보고되어 있다[16]. 따라서 많은 연구자들은 운 동이 SOCS-3의 발현을 억제할 것이라는 가설을 바탕으로 운 동과 SOCS-3의 관계를 밝히고자 하였으나, 12 주간의 규칙적 인 트레드밀 운동은 쥐의 족저근과 가자미근에서 SOCS-3 유 전자의 $\mathrm{mRNA}$ 발현을 오히려 증가시켰으며[31], 고강도의 저 항성 운동 후 사람의 대퇴부 외측광근에서도 SOCS-3 유전자 의 mRNA가 오히려 60 배 가량 증가하였다는 연구 결과가 보 
고되었다[35]. Lebrun [22] 등은 SOCS-3 유전자의 발현 증가가 세포 내의 인슐린과 IGF-I 신호전달의 중요 개시자인 insulin receptor substrate (IRS)의 활성화를 억제시킴으로써 인슐린 저항성을 증가시킨다고 보고하였다[22,27,32].

최근 인슐린과 insulin-like growth factor-I (IGF-I)이 구조 적 유사성이 높을 뿐만 아니라, 세포 내 신호전달 경로 체계를 상당부분 공유하기 때문에 SOCS-3가 IGF-I의 작용에도 관여 할 수 있을 것이라는 가능성이 제기되었다[6]. IGF-I은 근육 세포의 증식 및 분화 과정에 있어 중심적인 역할을 할 뿐만 아니라[10,11], 근육 관련 유전자들의 발현 및 전사 활성화를 증가시키고, 근단백질의 합성을 증가시킨다 $[10,11,18,23]$. 또한 염증 사이토카인 인 tumor necrosis factor-a (TNF- a)와 interleukin-1, 6 (IL-1,6) 등으로 인해 활성화되는 ubiquitin 합성 효소들의 발현을 억제함으로써 근위축의 진행을 억제하는 기 능을 한다[12]. 이와 같이 IGF-I은 동화작용 촉진 및 이화작용 억제를 통해 골격근의 성장, 발달, 부피 유지에 필수적인 역할 을 한다.

이렇듯 SOCS-3 유전자는 근육세포의 분화 및 형성과정이 나, 인슐린 신호전달체계에 있어 주요 조절자로써의 역할을 하며, IGF-I은 근비대 기전에 있어 동화작용을 함으로써 근육 관련 유전자 발현에 중심적인 역할을 한다. SOCS-3의 하부 target 인 Signal transducers and activators of transcription-3 (STAT-3)는 IGF-I 을 비롯한 다양한 성장인자들과 호르몬의 신호를 통해 활성화되는 전사 조절인자이며[25,33], 근육에서 는 IGF-I 에 의해 활성이 억제되는 IL-6에 의해 활성화 되는 것으로 보고되어있다[3,13]. 이와 같이 근육 관련 유전자 발현 의 조절자로써 SOCS-3와 IGF-I의 관련성과 상호작용에 대한 가능성이 직 간접적으로 제기되고 있지만 분화된 근육 세포에 서 IGF-I이 SOCS-3 유전자 발현에 미치는 영향에 관한 연구는 전무한 실정이다. 따라서 본 연구에서는 $\mathrm{C} 2 \mathrm{C} 12$ myotube에 IGF-I을 다양한 농도와, 시간 별로 처리하여 IGF-I에 의한 SOCS-3 유전자 발현의 변화를 알아보고자 하였다.

\section{재료 및 방법}

세포 배양 및 시약 처리

본 연구에서 사용한 $\mathrm{C} 2 \mathrm{C} 12$ 골격근 세포는 American Type of Culture Collection (ATCC, USA)으로부터 구입하였으며, $10 \%$ fetal bovine serum (FBS) (Hyclone, Logan, UT), 100 $\mathrm{U} / \mathrm{ml}$ 의 penicillin $\mathrm{G}$, 그리고 $100 \mu \mathrm{g} / \mathrm{ml}$ 의 streptomycin sulfate (Welgene, KOREA)를 함유하고 있는 Dulbecco's modified Eagle's medium (DMEM) (Welgene, KOREA) 으로 $37^{\circ} \mathrm{C}$, $5 \% \mathrm{CO}_{2}$ 의 환경에서 배양하였다. 세포는 $35 \mathrm{~mm}$ plate에 $2.5 \times 10^{5}$ 개씩 분주하고 $90 \%$ 이상 자라면, 성장배지를 제거하 고 $2 \%$ horse serum (HS) (Hyclone, Logan, UT)이 함유된 분화 배지로 교체한 뒤 96 시간 동안 분화를 유도하여 myotube를
형성시켰다. IGF-I 처리 농도 및 시간 경과에 따른 SOCS-3 유 전자의 단백질 및 $\mathrm{mRNA}$ 발현의 변화를 알아보기 위하여 농 도 $(10-100 \mathrm{ng} / \mathrm{ml})$ 및 시간 $(3,24,48,72$ 시간)에 따라 IGF-I (Sigma Aldrich, St. Louis, MO)을 처리하였다.

\section{Immunofluorescent staining}

$\mathrm{C} 2 \mathrm{C} 12$ 세포를 $\mathrm{PBS}$ 로 한번 씻어낸 뒤, plate에 고정시키기 위하여 $1 \mathrm{ml}$ 의 $4 \%$ formaldehyde를 상온에서 20 분간 처리한 뒤 TBS로 2 번 씻어내고, $0.2 \%$ triton X-100을 함유한 TBS $(0.2 \%$ $\mathrm{TBST}$ )로 5 분간 상온에서 permeabilizing하였다. 그 다음 $0.1 \%$ TBST로 5 분간 3번 씻어낸 후 5\% BSA를 함유한 $0.1 \%$ TBST로 상온에서 1 시간 동안 blocking 하였다. 이후 TBS로 한번 씻어 낸 뒤 3\% BSA를 함유한 TBS에 SOCS-3 polyclonal rabbit antibody (Santa Cruz Biotechnology, Santa Cruz, CA)를 1:500으 로 희석하여 $4^{\circ} \mathrm{C}$ 에서 12 시간 동안 반응시켰다. 그 후, $0.1 \%$ TBST로 5 분간 3 번 씻어낸 뒤 alexa 488-conjugated goat anti-rabbit IgG secondary antibody (Invitrogen Life Technologies, Carlsbad, CA)를 3\% BSA에 1:250으로 희석하 여 상온에서 20 분간 반응시킨 후 $0.1 \% \mathrm{TBST}$ 로 5 분간 3 번 씻어내었다. 사진은 digital imaging system이 갖춰진 Axiovert 200 fluorescence microscope (Carl Zeiss, Germany) 를 사용하여 촬영하였다.

\section{Western blot}

단백질을 추출하기 위하여 cell lysis buffer $(50 \mathrm{mM}$ Tris, pH 7.5, $150 \mathrm{mM} \mathrm{NaCl}, 1 \%$ Triton X-100, and complete protease inhibitor cocktail)를 처리하여 세포를 얻어낸 후 $4^{\circ} \mathrm{C}$ 에 서 $13,000 \mathrm{rpm}$ 으로 15 분간 원심분리 하였다. 분리된 단백질 을 얻어낸 뒤 Bradford protein assay kit (Bio-Rad, Hercules, $\mathrm{CA}$ )를 사용하여 단백질 농도를 측정하였다. 정량 된 $60 \mu \mathrm{g}$ 의 단백질을 $10 \%$ SDS-PAGE gel에서 $150 \mathrm{~V}$ 로 1 시간 동안 전기 영동 한 뒤, PVDF membrane으로 옮겨주었다(12 V, 1 시간). 그 후, Ponceau S로 모든 lane의 동량의 단백질을 확인한 후 각각의 membrane을 5\% skim milk로 1 시간 blocking 한 뒤 $0.1 \%$ TBST로 5 분씩 3 번 씻어내었다. 다음으로 SOCS-3 (polyclonal rabbit antibody, 1:1,000) (Santa Cruz Biotechnology, Santa Cruz, CA), 그리고 a-tubulin (monoclonal mouse antibody, 1:2,500) (Calbiochem, Gibbstown, NJ) 1 차 항체를 $5 \%$ bovine serum albumin(BSA) 에 희석하여 $4^{\circ} \mathrm{C}$ 에서 12 시간 반응시켰다. 1 차 항체 반응이 끝난 뒤, $0.1 \%$ TBST로 5 분씩 3 번 씻어낸 뒤 2 차 항체 (anti-rabbit or mouse IgG horse-radish peroxidase-linked secondary antibody, 1:5,000) (Cell signaling, Beverley, MA) 를 상온에서 1 시간 동안 반응시켰다. 반응이 끝난 후 위와 동일한 방법으로 씻어낸 뒤, enhanced chemiluminescent (ECL) (GE Healthcare UK Ltd., Little Chalfont, UK) 용액을 
1:1 비율로 섞어 1 분 동안 반응 시켜 LAS-3000 imaging system (Fuji Film, Tokyo, Japan)으로 단백질 발현양을 확인하였 다. SOCS-3 단백 질 발현양은 a-tubulin의 단백질 양으로 보정 하여 densitometry (Scion image)로 수치화 하였다.

\section{$\mathrm{RNA}$ 추출 및 $\mathrm{CDNA}$ 합성}

RNA추출은 TRIzol 용액(Invitrogen Life Technologies, Carlsbad, CA)을 이용한 phenol-chloroform 기법을 사용하였 다. TRIzol 용액을 well당 각각 $1 \mathrm{ml}$ 씩 넣고, $200 \mu \mathrm{ll}$ 의 chloroform을 처리하여 섞어준 뒤 $4^{\circ} \mathrm{C}, 13,000 \mathrm{rpm}$ 에서 15 분간 원심 분리를 하였다. 상층액을 분리하여 isoprophanol과 1:1 비율로 섞어준 뒤, $4^{\circ} \mathrm{C}, 12,000 \mathrm{rpm}$ 에서 10 분간 원심분리를 하였다. 생성된 pellet을 $\mathrm{DEPC}$ 로 희석한 $75 \% \mathrm{ETOH}$ 에 씻어내고, $4^{\circ} \mathrm{C}$, $12,000 \mathrm{rpm}$ 에서 5 분간 원심분리를 하였다. 최종 추출된 pellet 을 상온에서 10 분간 건조시킨 뒤 ultra pure water $30 \mu 1$ 에 녹인 후, UV 흡광도 $260 \mathrm{~nm}$ 에서 농도를 측정하였다. $1 \mathrm{\mu g} / \mathrm{\mu l}$ 의 RNA를 $5 \times$ buffer $4 \mu \mathrm{l}$, random primer $2 \mu \mathrm{l}, 2.5 \mathrm{mM}$ dNTP $2 \mu l$, Rnase inhibitor $0.5 \mu \mathrm{l}$, 그리고 reverse transcriptase 0.25 ul (Invitrogen Life Technologies, Carlsbad, CA)와 혼합하여 $25^{\circ} \mathrm{C}$ 에서 10 분, $42^{\circ} \mathrm{C}$ 에서 60 분, 그리고 $95^{\circ} \mathrm{C}$ 에서 5 분간 $\mathrm{PCR}$ 을 이용해 $\mathrm{cDNA}$ 를 합성하였다.

\section{Real-time quantitative PCR}

SOCS-3의 mRNA 발현을 측정하기 위하여 double-stranded DNA dye인 SYBR Green PCR master mix (Finnzyme, Espoo, Finland)를 이용하여 real-time PCR (ABI PRISM 7700 system) (Applied Biosystems Inc., Foster City, $\mathrm{CA}$ )을 실시하였다. 사용한 primer sequence는 Table 1에 제시 하였으며, 모든 Primer는 코스모사(Cosmo Genetech, Korea) 에서 제작 및 구입하여 사용하였다. 모든 샘플은 3회 반복 실 험하여 합성시킨 $\mathrm{cDNA}$ 를 2회 이상 반복 측정하였다. $95^{\circ} \mathrm{C}$ 15 초, $60^{\circ} \mathrm{C} 30$ 초간 $40 \mathrm{cycle}$ 을 측정하여 $\mathrm{CT}$ 값을 얻어내고, 융해 곡선 확인을 위해 40 cycle 이후 dissociation stage를 추 가하여 $95^{\circ} \mathrm{C} 15$ 초, $60^{\circ} \mathrm{C} 1$ 분의 조건을 2 번 반복하여 현광 신호의 크기를 측정하였다. 반응이 완료된 후 증폭곡선의 S 커브가 급격히 올라가는 지점과 CT 값의 추출 지점이 일치하 였음을 확인하고, 융해 곡선 그래프의 단일 증폭 곡선을 확인 한 뒤 최종적으로 CT 값을 데이터 처리 하였다. 결과는 단순 $\mathrm{CT}$ 값 비교 분석 방법을 사용하였으며, mRNA 발현양은 glyceraldehyde 3-phosphate dehydrogenase (GAPDH)의 CT값으
로 상대 정량하여 보정하였다.

\section{자료처리}

IGF-I 처리에 따른 C2C12 세포에서의 SOCS-3 유전자의 단 백질 발현과 mRNA 발현의 유의성 검증을 위하여 SPSS 12.0 for window를 이용하여 일원배치분산분석(one-way ANOVA) 을 실시하였으며, 농도 및 시간 별로 유의한 차이가 있는지를 검증하기 위하여 Tukey's 사후검정을 실시하였다 $(p<0.05)$.

\section{결 과}

C2C12 myotube에서 IGF-I이 SOCS-3 유전자의 단백질 발 현에 미치는 영향을 형태적으로 살펴보기 위하여 $10,50,100$ $\mathrm{ng} / \mathrm{ml}$ 의 IGF-I을 각각 24 시간 동안 처리하여 immunofluroscent staining을 통한 형광현미경 관찰을 실시하였다. 그 결과 Fig. 1에 제시된 바와 같이 IGF-I을 처리하지 않은 myotube (Fig. 1A)와 비교하였을 때, 24 시간 동안 다양한 농도 별로 IGF-I을 처리한 Fig. $1 \mathrm{~B}(10 \mathrm{ng} / \mathrm{ml}), 1 \mathrm{C}(50 \mathrm{ng} / \mathrm{ml}), 1 \mathrm{D}$ $(100 \mathrm{ng} / \mathrm{ml})$ myotube에서는 IGF-I 농도 의존적으로 SOCS-3 단백질 발현이 현저하게 증가되었음을 관찰 할 수 있었다.

IGF-I이 SOCS-3 유전자의 단백질 발현에 미치는 영향을 알 아보기 위하여 96 시간 동안 분화시킨 $\mathrm{C} 2 \mathrm{C} 12$ myotube에 200 $\mathrm{ng} / \mathrm{ml}$ 의 IGF-I을 각각 $24,48,72$ 시간 동안 처리하여 Western blot 분석을 실시하였다. 그 결과 Fig. $2 \mathrm{~A}$ 에 제시된 바와 같이 IGF-I을 24 시간 동안 처리하자 통제군에 비해 SOCS-3 단백질 발현이 약 $66 \%$ 유의하게 증가하였으며, Fig. 2B에 나타난 바와 같이 48 시간 동안 IGF-I을 처리하자 통제군과 비교하였을 때 SOCS-3의 단백질 발현이 약 $82 \%$ 유의하게 증가하였다. 또한 IGF-I을 72 시간 동안 처리하자 SOCS-3 단백질 발현이 통제군 과 비교하였을 때 약 $127 \%$ 유의하게 증가하였음을 알 수 있었 다(Fig. 2C).

IGF-I이 SOCS-3 mRNA 발현에 어떠한 영향을 미치는지 알아보기 위해 C2C12 myotube에 10, 50, $100 \mathrm{ng} / \mathrm{ml}$ 의 IGF-I 을 시간 별로 처리하여 real-time PCR 분석을 실시하였다(Fig. 3). 그 결과 IGF-I을 3 시간 동안 처리하자 가장 낮은 농도인 $10 \mathrm{ng} / \mathrm{ml}$ 에서 약 $120 \%, 50 \mathrm{ng} / \mathrm{ml}$ 에서 $162 \%$ 정도로 SOCS-3 $\mathrm{mRNA}$ 발현이 농도 의존적으로 유의하게 증가하였다. 그러나 가장 높은 농도인 $100 \mathrm{ng} / \mathrm{ml}$ 에서는 약 $74 \%$ 정도로 발현이 증가하였으나 통계적으로 유의하지는 않았으며, 상대적으로 낮은 농도인 $10,50 \mathrm{ng} / \mathrm{ml}$ 에서의 결과와 비교하였을 때 SOCS-3 mRNA 발현의 증가 정도가 보다 적었음을 알 수 있었

Table 1. Primer sequences for real-time PCR

\begin{tabular}{cll}
\hline Gene & Forward primers & Reverse primers \\
\hline SOCS-3 & GGACCAGCGCCACTTCTTCAC & TACTGATCCAGGAACTCCCGA \\
\hline GAPDH & ATGACAATGAATACGGCTACAGCAA & GCAGCGAACTTTATTGATGGTATT \\
\hline
\end{tabular}




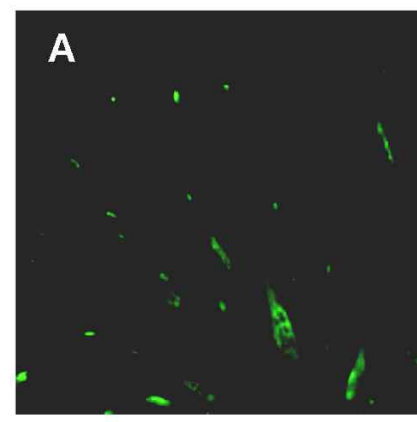

Con

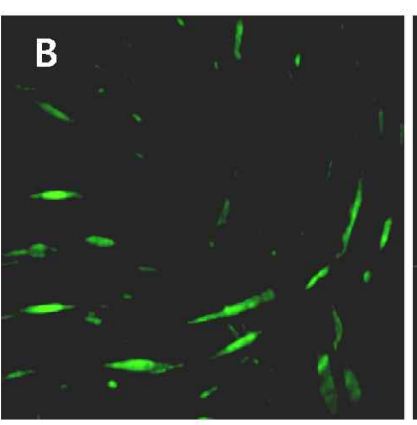

10

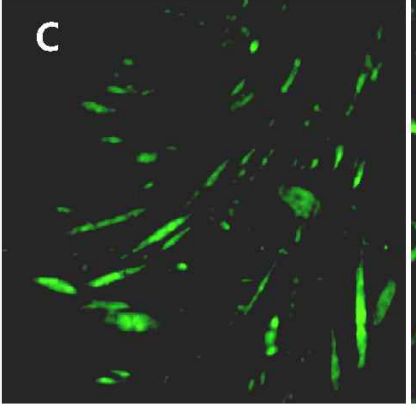

50

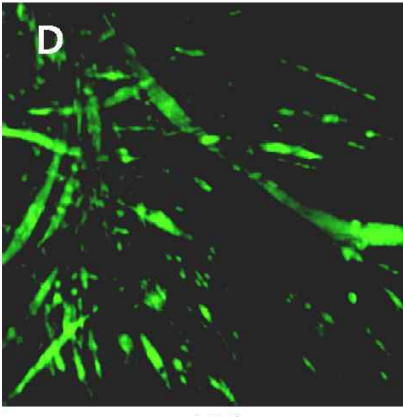

100

IGF-I ( $\mathrm{ng} / \mathrm{ml})$

Fig. 1. Immunofluorescent staining images showing IGF-I-induced SOCS-3 protein expression in C2C12 myotubes. All images were acquired at $24 \mathrm{hr}$ after treatment. (A) C2C12 myotubes in IGF-I free medium. (B) C2C12 myotubes in medium containing $10 \mathrm{ng} / \mathrm{ml}$ of IGF-I. (C) C2C12 myotubes in medium containing $50 \mathrm{ng} / \mathrm{ml}$ of IGF-I. (D) C2C12 myotubes in medium containing $100 \mathrm{ng} / \mathrm{ml}$ of IGF-I. SOCS-3 is stained fluorescent green.

다(Fig. 3A). 반면에 Fig. 3B에 제시된 바와 같이 $50,100 \mathrm{ng} / \mathrm{ml}$ 의 IGF-I을 24 시간 동안 처리하자 $\mathrm{C} 2 \mathrm{C} 12$ myotube에서의 SOCS-3 mRNA 발현은 $50 \mathrm{ng} / \mathrm{ml}$ 에서 $29 \%, 100 \mathrm{ng} / \mathrm{ml}$ 에서 $44 \%$ 유의하게 감소하였다. 더 나아가 IGF-I을 48 시간 동안 처리하자 SOCS-3 mRNA 발현이 각각 $10 \mathrm{ng} / \mathrm{ml}$ 에서 $39 \%$, $50 \mathrm{ng} / \mathrm{ml}$ 에서 $47 \%, 100 \mathrm{ng} / \mathrm{ml}$ 에서 $52 \%$ 정도로 현저히 감소 하였음을 확인 할 수 있었다(Fig. 3C). 종합하여 보면 IGF-I 처리에 따른 시간별 SOCS-3 mRNA 발현의 변화 양상은 3 시간에서 농도 의존적으로 증가하였고, 24,48 시간 동안 IGF-I 을 처리한 그룹에서는 SOCS-3 mRNA 발현이 감소하였음을 알 수 있었다.

\section{고 찰}

근육에서의 SOCS-3 유전자에 관한 연구들을 살펴보면, 쥐 의 근육 세포의 분화과정에서 SOCS-3 mRNA가 증가하였으 며 SOCS-3를 과발현 시키자 근육관련 전사인자인 SRF의 전사 활성화가 급격히 증가하여 skeletal a-actin, myogenin 등과 같은 근육 관련 유전자의 $\mathrm{mRNA}$ 발현을 증가시켰다고 보고하 였다[30]. 또한 지구성 운동 및 고강도 저항성 트레이닝은 근육 조직에서의 SOCS-3 발현을 유의하게 증가시켰다고 보고되었 다[31,35]. 그러나, SOCS-3 유전자의 발현은 인슐린 저항성을 유의하게 높인다고 알려져 있다[8,9,29]. 관련 연구들에 따르 면, 인슐린 저항성을 보이는 비만이 유도된 쥐의 뒷다리 근육 에서 SOCS-3 단백질 발현이 유의하게 증가하였으며[41], 쥐의 간 세포에 SOCS-3 유전자를 과발현 시키자 인슐린 저항성이 유도 되었음을 보고하였다 $[9,36]$. 반대로 당뇨병이 유발된 쥐 에서 SOCS-3 발현을 억제시키자 인슐린 저항성이 부분적으로 개선되었음을 보고하였다[37].

운동은 인슐린 저항성을 낮춰주는 동시에 인슐린 민감성을
개선시켜 효과적인 글루코스 연소 작용을 이끌어줌으로써 정 상적인 대사활동이 이루어지도록 한다[15]. 따라서 당뇨병 환 자들에 있어 규칙적인 운동은 필수적인 치료 요법으로 알려져 있다. 특히, 비만 상태로 유도된 동물 모델에 있어 운동이 인슐 린 저항성을 효과적이게 낮추어 주었다고 보고하였다[20,21]. 이렇듯 운동과 비만, 운동과 인슐린 저항성 감소의 관계는 지 금까지 매우 잘 연구 되어진 주제이다. 그러나 이와 같은 선행 연구들을 종합해보면 운동은 인슐린 저항성을 낮춰주지만, 운 동은 인슐린 저항성을 유도하는 SOCS-3 유전자 발현을 증가 시킨다는 역설적인 결론이 도출된다. 선행 연구들에서는 이러 한 현상을 다음과 같이 설명하였다. 운동으로 증가하는 염증 성 사이토카인이자 골격근에서 직간접적으로 이화작용을 하 는 IL-6의 증가는 성장호르몬, IGF-I, 인슐린 작용에 의존하는 것으로 알려진 Janus kinase (JAK)/STAT 신호전달 경로의 부 적 조절자(negative regulator)인 SOCS-3 발현을 증가시키고, SOCS-3 유전자 발현의 증가는 STAT-3에 의존적인 성장인자 들의 민감성을 억제시키기 때문에 이것이 인슐린 저항성으로 연결될 것이라고 설명하였다 $[1,4,13,29,31]$. 그러나 IL-6와 인슐 린 저항성에 관련된 다른 연구들에 의하면, IL-6가 골격근에서 인슐린 민감성을 높여줄 수 있으며[39], 쥐에서 IL-6 유전자를 knock out하여 9개월간 사육하자 제 2형 당뇨병이 유발되었음 을 보고하였다[38]. 나아가 위와 같은 선행 연구의 결과들과 상반되게 Rieussert [26] 등은 비만이지만 당뇨병이 없는 사람 들에게서 골격근에서의 SOCS-3 유전자의 발현과 인슐린 저항 성은 유의한 상관이 없었다고 보고하였다. 이러한 결과들에 미루어밨을 때, 인슐린 저항성에 있어 SOCS-3와 IL-6와의 상 관 관계에 대한 연구는 보다 상세한 추가 연구가 이루어져야 할 것으로 사료된다.

본 연구에서의 결과를 살펴보면 앞선 관련 연구들과 비슷한 경향을 관찰 할 수 있었다. 운동으로 인해 체내 분비가 증가하 

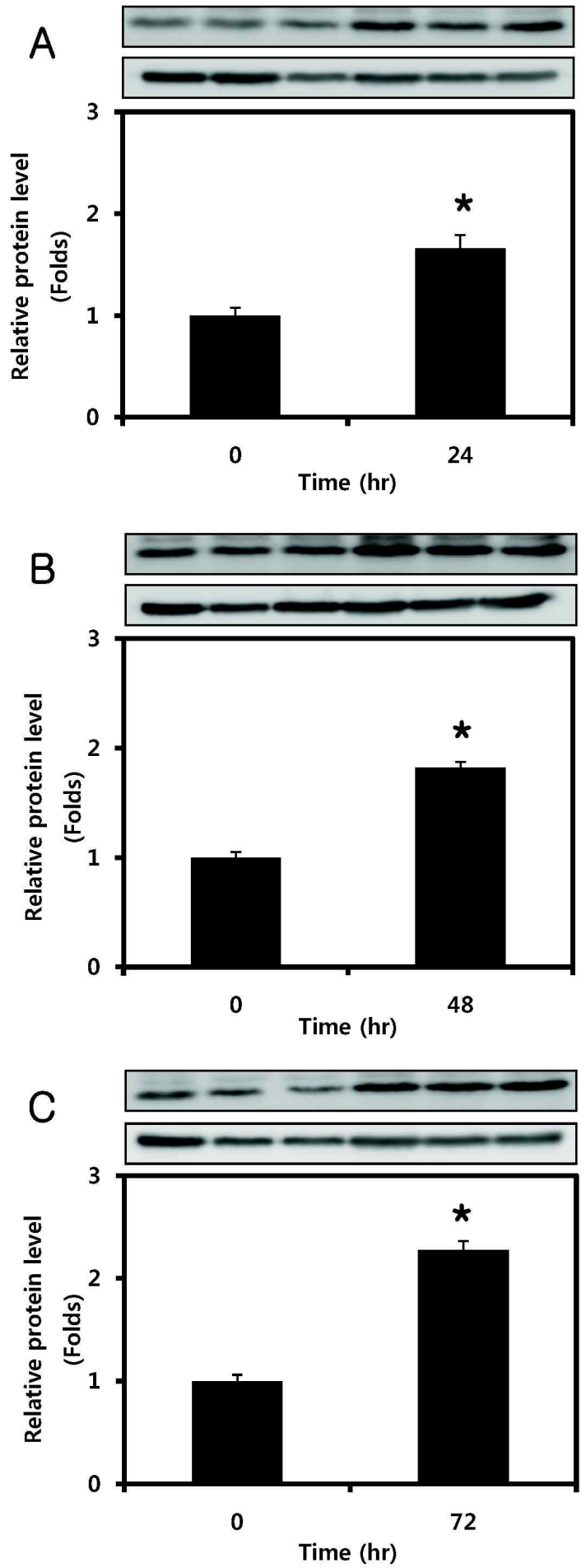

Fig. 2. Effect of different lengths of time on SOC-3 protein expression in $\mathrm{C} 2 \mathrm{C} 12$ myotubes. (A) $\mathrm{C} 2 \mathrm{C} 12$ myotubes were treated with $200 \mathrm{ng} / \mathrm{ml}$ of IGF-I for $24 \mathrm{hr}$. (B) C2C12 myotubes were treated with $200 \mathrm{ng} / \mathrm{ml}$ of IGF-I for 48 hr. (C) C2C12 myotubes were treated with $200 \mathrm{ng} / \mathrm{ml}$ of IGF-I for $72 \mathrm{~h}$. Values are means \pm SE with $n=3$ for each condition. ${ }^{*} p<0.05$ vs. control.
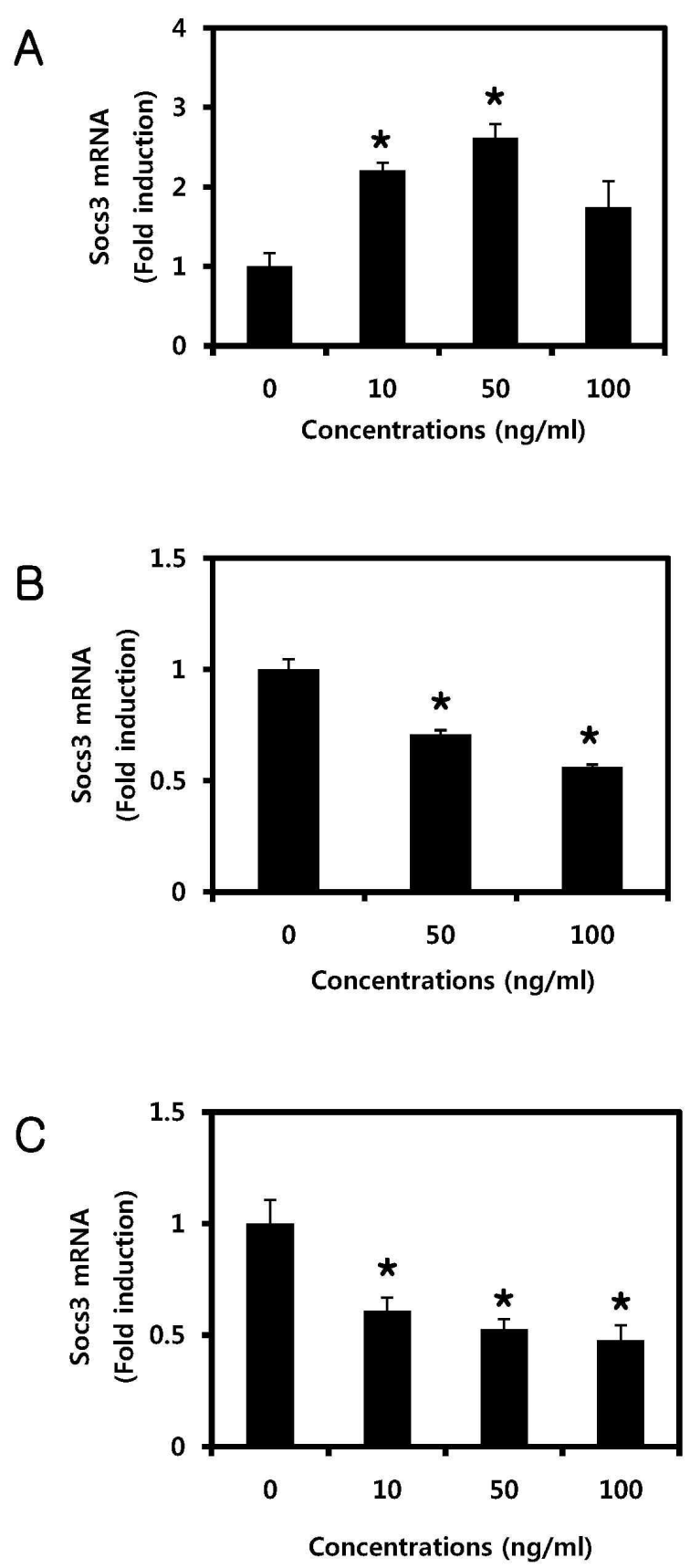

Fig. 3. Real-time PCR analysis of SOCS-3 mRNA after treatment with IGF-I (A). C2C12 myotubes were treated with 0 , 10, 50, or $100 \mathrm{ng} / \mathrm{ml}$ of IGF-I for $3 \mathrm{hr}$. (B) C2C12 myotubes were treated with 0,50 , or $100 \mathrm{ng} / \mathrm{ml}$ of IGF-I for $24 \mathrm{hr}$. (C) C2C12 myotubes were treated with 0, 10, 50 , or $100 \mathrm{ng} / \mathrm{ml}$ of IGF-I for $48 \mathrm{hr}$. Data are normalized to control, and values are means \pm SE with $n=3$ for each condition. ${ }^{*} p<0.05$ vs. control.

는 IGF-I을 생리적 농도(physiological concentration)로 간주 되는 $200 \mathrm{ng} / \mathrm{ml}$ 의 범위 내의 농도인 $10-100 \mathrm{ng} / \mathrm{ml}$ 를[17] myotube에 처리하였을 때, $50 \mathrm{ng} / \mathrm{ml}$ 에서 SOCS-3의 mRNA 
발현을 3 시간에서 최고 $162 \%$ 가량 증가시켰으며 시간이 지남 에 따라 발현이 감소되었다. 또한 IGF-I은 SOCS-3의 단백질 발현을 시간 의존적으로 유의하게 증가시켰음을 알 수 있었 다. 이러한 결과들과 선행 연구들을 종합하여, IGF-I과 관련된 신호전달 경로 중 하나인 JAK/STAT 경로와 SOCS-3의 관계 를 살펴 볼 필요가 있다. SOCS-3가 부적반응 작용을 하는 것으 로 알려진 STAT-3는 IL-6, IL-10 등의 사이토카인 뿐만 아니라 IGF-I, hepatocyte growth factor, epidermal growth factor, PDGF, basic fibroblast growth factor, RhoA 등과 같은 다양한 성장인자들 및 호르몬의 신호를 통해서도 활성화되는 전사조 절인자이다 $[19,25,33,40]$. STAT-3를 활성화 시키는 IL-6는 성 장호르몬 및 IGF-I의 신호전달 경로에 간섭할 수 있다는 가능 성이 제기되었으며[3], 최근 보고에 따르면 IL-6를 주입한 쥐의 근육조직에서 SOCS-3 유전자의 mRNA와 IGF-I의 mRNA가 유의하게 증가하였으며, STAT-3의 인산화가 유의하게 증가하 였다고 보고하였으나[13], 아직까지 자세한 기전은 밝혀지지 않았다.

기존의 연구에서 근육 세포의 증식과 분화과정 및 운동에 따른 SOCS-3 발현을 연구한 반면에 본 연구에서는 분화가 완 전히 진행된 myotube에 운동으로 인해 분비가 증가하는 IGF-I을 처리함으로써, 성숙된 근육 세포에서의 IGF-I에 의한 SOCS-3 유전자 발현의 변화를 관찰 할 수 있었다. 따라서 분화 가 진행되고 있는 경우에 비해 상대적으로 빠른 시간인 처리 후 3 시간에서 mRNA 발현이 증가되고, 24 시간 이후로 $\mathrm{mRNA}$ 수준이 감소하는 경향을 관찰하였는데, 이는 번역 (translation) 전 단계에서 단백질 발현이 증가한 것이라고 사 료된다. 또한 immunostaining을 통해 제시된 그림에서 볼 수 있듯이, 24 시간 동안 IGF-I 처리 농도가 증가할수록 SOCS-3 단백질이 염색된 myotube가 더 많이 관찰되었고, $24,48,72$ 시간이 지날수록 단백질 발현이 증가함을 관찰함으로써 IGF-I 이 SOCS-3 발현에 유의한 영향을 미친다는 것을 다시 한번 검증할 수 있었다. 이와 같이 본 연구에서는 myotube에서 IGF-I이 SOCS-3 유전자 발현에 유의한 영향을 미친다는 사실 을 처음으로 밝혀내었다. SOC-3와 IGF-I이 근육 세포 내에서 서로 다른 복잡한 경로로 근육 형성과정이나 골격근 관련 유 전자를 발현에 관여한다고 알려져 있지만, 근육에서 이 두 가 지 요소들의 관계에 관한 연구는 전무한 실정이었다. 더욱이 근육 형성과정과 분화가 완료된 myotube에서의 유전자 조절 기전이 매우 상이함에도 불구하고, myotube에서의 SOCS-3 유전자 발현에 관련한 연구는 이루어지지 않았다.

본 연구의 결과는 운동이 근육에서 SOCS-3 유전자 발현을 증가시켰음을 보고한 선행연구 결과들과 관련하여, 운동에 의 해 증가되는 IGF-I이 SOCS-3 유전자 발현에 중추적인 역할을 하는 것으로 사료된다. 비록 운동이 근육에서의 SOCS-3 유전 자 발현을 증가시키는데 있어 다양한 조절기전이 있을 것이라 예상되지만, IGF-I은 운동에 의해 증가하여 근육 세포 내에서
매우 중요한 역할을 하는 조절자로 잘 알려져 있기 때문에 본 연구 결과가 앞으로 근육 관련 연구에 있어 운동과 SOCS-3, SOCS-3와 IGF-I, IGF-I과 SOCS-3 유전자 및 인슐린 대사에 있어 명확히 밝혀지지 않은 기전을 증명해 나아가는데 중요한 단서를 제공할 수 있을 것이라 생각된다. 그러나 본 연구에서 는 IGF-I의 하부 신호전달 경로와 SOCS-3 간의 관계, 그리고 선행 연구들에서 제기된 IL-6와의 관계에 대한 연구는 수행하 지 못하였다. 따라서 IGF-I이 근육 관련 유전자의 발현을 증가 시키는데 있어 SOCS-3의 역할을 보다 명확히 설명하기 위해 서는, SOCS-3 유전자와 IGF-I 고유의 신호전달 경로로 밝혀져 있는 phosphoinositide 3-kinase (PI3K), mitogen activated protein kinase (MAPK) 신호전달 경로와의 관계 및 JAK/STAT 경로와 관련한 연구가 반드시 이루어져야 할 것이 라 생각된다. 또한 운동으로 인한 SOCS-3 유전자 발현 증가와 SOCS-3 발현 증가에 따른 인슐린 저항성의 증가에 대한 기전 적 연구가 더 필요할 것이라 사료된다. 그리고 나서 운동과 인슐린, 운동과 사이토카인, 그리고 SOCS-3 유전자 발현간의 역설적 관계에 대한 기전을 명확히 밝혀나가야 할 것이며, 나 아가 골격근 관련 유전자의 발현 및 전사 활성화에 관한 연구 가 추가적으로 이루어져야 할 것이라 생각된다.

\section{References}

1. Alexander, W. S. and D. J. Hilton. 2004. The role of suppressors of cytokine signaling (SOCS) proteins in regulation of the immune response. Annu. Rev. Immunol. 22, 503-529.

2. Auernhammer, C. J., C. Bousquet, A. Chensnokova, and S. Meled. 2000. SOCS proteins: modulators of neuroimmunoendocrine functions. Impact on corticotroph LIF signaling. Ann. N. Y. Acad Sci. 917, 658-664.

3. Benedetti, F., T. Alonzi, A. Moretta, D. Lazzaro, P. Costa, V. Poli, A. Martini, G. Ciliberto, and E. Fattori. 1997. Interleukin 6 causes growth impairment in transgenic mice through a decrease in insulin-like growth factor-I. A model for stunted growth in children with chronic inflammation. J. Clin. Invest. 99, 643-650.

4. Bodell, P. W., E. Kodesh, F. Haddad, F. P. Zaldivar, D. M. Cooper, and G. R. Adams. 2009. Skeletal muscle growth in young rats is inhibited by chronic exposure to IL-6 but preserved by concurrent voluntary endurance exercise. J. Appl. Physiol. 106, 443-453.

5. Cacalano, N. A., D. Sanden, and J. A. Johnston. 2001. Tyrosine-phosphorylated SOCS-3 inhibits STAT activation but binds to p120 RasGAP and activates Ras. Nat. Cell Biol. 3, 460-465.

6. Dey, B. R., R. W. Furlanetto, and P. Nissley. 2000. Suppressor of cytokine signaling (SOCS)-3 protein interacts with the insulin-like growth factor-I receptor. Biochem Biophys. Res. Commun. 278, 38-43.

7. Diao, Y., X. Whang, and Z. Wu. 2009. SOCS1, SOCS3, and PIAS1 promote myogenic differentiation by inhibiting the 
leukemia inhibitory factor-induced JAK1/STAT1/STAT3 pathway. Mol. Cell Biol. 29, 5084-5093.

8. Emanuelli, B., P. Peraldi, C. Filloux, D. Sawaka-Verhelle, D. J. Hilton, and E. Van Obberghen. 2000. SOCS-3 is an insulin-induced negative regulator of insulin signaling. J. Biol. Chem 275, 15985-15991.

9. Emanuelli, B., P. Peraldi, C. Filloux, C. Chavey, K. Freidinger, D. J. Hilton, G. S. Hotamisligil, and E. Van Obberghen. 2001. SOCS-3 inhibits insulin signaling and is up-regulated in response to tumor necrosis factor-alpha in the adipose tissue of obese mice. J. Biol. Chem 276, 47944-47949.

10. Florini, J. R., D. Z. Ewton, and S. A. Coolican. 1996. Growth hormone and the insulin-like growth factor system in myogenesis. Endocr. Rev. 16, 481-517.

11. Galvin, C. D., O. Hardiman, and C. M. Nolan. 2003. IGF-I receptor mediates differentiation of primary cultures of mouse skeletal myoblasts. Mol. Cell Endocrinol. 200, 19-29.

12. Glass, D. J. 2005. Skeletal muscle hypertrophy and atrophy signaling pathways. Int. J. Biochem Cell Biol. 37, 1974-1984.

13. Haddad, F., F. Zaldivar, D. M. Cooper, and G. R. Adams. 2005. IL-6-induced skeletal muscle atrophy. J. Appl. Physiol. 98, 911-917.

14. Hansen, J. A., K. Lindberg, D. J. Hilton, J. H. Nielsen, and N. Billestrup. 1999. Mechanism of inhibition of growth hormone receptor signaling by suppressor of cytokine signaling proteins. Mol. Endocrinol. 13, 1832-1843.

15. Hawley, J. A. and S. J. Lessard. 2008. Exercise training-induced improvements in insulin action. Acta. Physiologica 192, 127-135.

16. Holloszy, J. O. 2005. Exercise-induced increase in muscle insulin sensitivity. J. Appl. Physiol. 99, 338-343.

17. Jandziszak, K., C. Suarez, E. Wasserman, R. Clark, B. Baker, F. Liu, R. Hintz, P. Saenger, and L. P Brion. 1998. Disturbances of growth hormone-insulin-like growth factor axis and response to growth hormone in acidosis. Am J. Physiol. 275, R120-R128.

18. Jennische, E. and H. A. Hansson. 1987. Regenerating skeletal muscle cells express insulin-like growth factor I. Acta. Physiol. Scand 130, 327-332.

19. Kakisis, J. D., C. D. Liapis, and B. E. Sumpio. 2004. Effects of cyclic strain on vascular cells. Endothelium 11, 17-28.

20. Kim, C. H., J. H. Youn, J. Y. Park, S. K. Hong, K. S. Park, S. W. Park, K. I. Suh, and K. U. Lee. 2000. Effects of high-fat diet and exercise training on intracellular glucose metabolism in rats. Am J. Physiol. 278, E977-E984.

21. Kraegen, E. W., D. E. James, A. B. Jenkins, D. J. Chisholm, and L. H. Storlien. 1989. A potent in vivo effect of ciglitazone on muscle insulin resistance induced by high fat feeding of rats. Metabolism 38, 1089-1093.

22. Lebrun, P. and E. Van Obberghen. 2008. SOCS proteins causing trouble in insulin action. Acta. Physiologica 192, 29-36.

23. McLellan, A. S., T. Kealey, and K. Langlands. 2006. An E box in the exon 1 promoter regulates insulin-like growth factor-I expression in differentiating muscle cells. Am J.
Physiol. 291, C300-C307.

24. Nielsen, C., L. C. Gormsen, N. Jessen, S. B. Pedersen, N. Møller, S. Lund, and J. O. Jørgensen. 2008. Growth hormone signaling in vivo in human muscle and adipose tissue: impact of insulin, substrate background, and growth hormone receptor blockade. J. Clin. Endocrinol. Metab. 93, 2842-2850.

25. Park, P. and P. Cohen. 2005. Insulin-like growth factor I (IGF-I) measurements in growth hormone (GH) therapy of idiopathic short stature (ISS). Growth Horm IGF Res. 15, S13-S20.

26. Rieusset, J., K. Bouzakri, E. Chevillotte, N. Ricard, D. Jacquet, J. P. Bastard, M. Laville, and H. Vidal. 2004. Suppressor of cytokine signaling 3 expression and insulin resistance in skeletal muscle of obese and type 2 diabetic patients. Diabetes 53, 2232-2241.

27. Rui, L., M. Yuan, D. Frantz, S. Shoelson, and M. F. White. 2002. SOCS-1 and SOCS-3 block insulin signaling by ubiquitin-mediated degradation of IRS1 and IRS2. J. Biol. Chem 277, 42394-42399.

28. Sadowski, C. L., T. S. Choi, M. Le, T. T. Wheeler, L. H. Wang, and H. B. Sadowski. 2001. Insulin Induction of SOCS-2 and SOCS-3 mRNA expression in C2C12 Skeletal Muscle Cells Is Mediated by Stat5*. J. Biol. Chem 276, 20703-20710.

29. Shi, H., I. Tzameli, C. Bjorbaek, and J. S. Flier. 2004. Suppressor of cytokine signaling 3 is a physiological regulator of adipocyte insulin signaling. J. Biol. Chem 279, 34733-34740.

30. Spangenburg, E. E. 2005. SOCS-3 induces myoblast differentiation. J. Biol. Chem 280, 10749-10758.

31. Spangenburg, E. E. 2006. Exercise increases SOCS-3 expression in rat skeletal muscle: potential relationship to IL-6 expression. J. Physiol. 572, 839-848.

32. Steppan, C. M., J. Wang, E. L. Whiteman, M. J. Birnbaum, and M. A. Lazer. 2005. Activation of SOCS-3 by resistin. Mol. Cell Biol. 25, 1569-1575.

33. Takeda, K. and S. Akira. 2000. STAT family of transcription factors in cytokine-mediated biological responses. Cytokine. Growth. Factor Rev. 11, 199-207.

34. Tollet-Egnell, P., A. Flores-Morales., A. Stavréus-Evers., L. Sahlin, and G. Norstedt. 1999. Growth hormone regulation of SOCS-2, SOCS-3, and CIS messenger ribonucleic acid expression in the rat. Endocrinology 140, 3693-3704.

35. Trenerry, M. K., K. A. Carey, A. C. Ward, and D. Cameron-Smith. 2007. STAT3 signaling is activated in human skeletal muscle following acute resistance exercise. $J$. Appl. Physiol. 102, 1483-1489.

36. Ueki, K., T. Kondo, and C. R. Kahn. 2004. Suppressor of cytokine signaling 1 (SOCS-1) and SOCS-3 cause insulin resistance through inhibition of tyrosine phosphorylation of insulin receptor substrate proteins by discrete mechanisms. Mol. Cell Biol. 24, 5434-5446.

37. Ueki, K., T. Kondo, Y. H. Tseng, and C. R. Kahn. 2004. Central role of suppressors of cytokine signaling proteins in hepatic steatosis, insulin resistance, and the metabolic syndrome in the mouse. Proc. Natl. Acad Sci. USA 101, 
$10422-10427$.

38. Wallenius, V., K. Wallenius, B. Ahrén, M. Rudling, H. Carlsten, S. L. Dickson, C. Ohlsson, and J. O. Jansson. 2002. Interleukin-6-deficient mice develop mature-onset obesity. Nat. Med 8, 75-79.

39. Weigert, C., A. M. Hennige, K. Brodbeck, H. U. Häring, and E. D. Schleicher. 2005. Interleukin-6 acts as insulin sensitizer on glycogen synthesis in human skeletal muscle cells by phosphorylation of Ser473 of Akt. Am J. Physiol. 289, E251-257.
40. Yadav, A., A. Kalita, S. Dhillon, and K. Banerjee. 2005. JAK/STAT3 pathway is involved in survival of neurons in response to insulin-like growth factor and negatively regulated by suppressor of cytokine signaling-3. J. Biol. Chem 280, 31830-31840.

41. Yaspelkis, B. B. III., I. A. Kvasha, and T. Y. Figueroa. 2009. High-fat feeding increases insulin receptor and IRS-1 coimmunoprecipitation with SOCS-3, IKKalpha/beta phosphorylation and decreases PI-3 kinase activity in muscle. Am J. Physiol. 296, R1709-R1715.

초록 : C2C12 myotube에서 insulin-like growth factor-I이 SOCS-3 유전자 발현에 미치는 영향

김혜진 · 이원준*

(이화여자대학교 건강과학대학 체육과학과)

SOCS-3와 IGF-I은 근육의 분화 과정 및 근비대 기전에 있어 매우 중요한 조절자 역할을 하는 유전자 및 성장인 자이며, 최근 골격근에서 IGF-I과 SOCS-3 유전자의 상호작용에 관한 연구의 필요성이 제기되고 있다. 본 연구에서 는 C2C12 myotube에서 IGF-I이 SOCS-3 유전자 발현에 미치는 영향에 대해 알아보기 위해 4 일간 분화시킨 C2C12 myotube에 IGF-I을 다양한 농도 $(0-200 \mathrm{ng} / \mathrm{ml})$ 및 시간 $(3-72$ 시간)에 따라 처리하였다. 그 결과 IGF-I이 SOCS-3 유전자의 단백질 발현을 시간 의존적으로 유의하게 증가시켰으며, 3 시간에서 $\mathrm{mRNA}$ 발현을 증가시키고, 시간이 지남에 따라 긴 시간에서는 농도 의존적으로 발현이 감소하였음을 알 수 있었다. 또한 면역형광 염색을 통해 IGF-I 이 myotube에서 SOCS-3의 단백질을 발현 시켰음을 뚜렷하게 관찰 할 수 있었다. 위 결과들을 바탕으로 본 연구에 서는 IGF-I의 처리가 분화된 근육 세포인 C2C12 myotube에서 SOCS-3 유전자 발현에 유의한 영향을 미쳤음을 증명하였다. 이러한 결과는 선행연구에서 보고한 운동이 SOCS-3 유전자 발현을 증가시킴에 있어서 IGF-I이 중추 적인 역할을 한 것으로 생각된다. 그러나 IGF-I에 의한 SOCS-3 유전자 발현 조절 기전에 있어 관련 신호 전달 체계 및 골격근 관련 유전자 발현에 미치는 영향에 관한 연구는 보다 더 이루어져야 할 것이라 사료된다. 